02

\title{
Оптические и фотолюминесцентные свойства тонкой пленки оксида цинка на подложке из тантала лития
}

\author{
(С) Л.В. Григорьев ${ }^{1,2}$, А.А. Семенов ${ }^{2}$, А.В. Михайлов ${ }^{3}$ \\ ${ }^{1}$ Санкт-Петербургский государственный университет, \\ 199034 Санкт-Петербург, Россия \\ ${ }^{2}$ Санкт-Петербургский государственный электротехнический университет „ЛЭТИ“, \\ 197022 Санкт-Петербург, Россия \\ ${ }^{3}$ АО „ГОИ им. С.И. Вавилова“, \\ 199053 Санкт-Петербург, Россия \\ e-mail: Ivgrigoryev@mail.ru
}

Поступила в редакцию 25.07.2021 г.

В окончательной редакции 25.07.2021 г.

Принята к публикации 01.10.2021 г.

\begin{abstract}
Представлены результаты исследования структурных, оптических и фотолюминесцентных свойств тонкой пленки оксида цинка на подложке из $\mathrm{LiTaO}_{3}$. Приведены результаты рентгеноструктурного анализа пленки оксида цинка, синтезированной на подложке из монокристаллического танталата лития и на подложке из кварца КУ-1. Приведены спектры пропускания, спектры отражения, спектры поглощения, спектральная зависимость фотолюминесценции тонкой пленки $\mathrm{ZnO}$ на сегнетоэлектрической подложке $\mathrm{LiTaO}_{3}$ и структуры $\mathrm{ZnO}$-кварц в ультрафиолетовом и видимом диапазонах спектра. Приведены результаты восстановления методом регуляризации Тихонова-Лаврентьева энергетического спектра оптически активных дефектов, присутствующих в структуре $\mathrm{ZnO}-\mathrm{LiTaO}_{3}$.
\end{abstract}

Ключевые слова: тонкие пленки, оксид цинка, лазерная абляция, сегнетоэлектрические материалы, фотолюминесценция, рентгеноструктурный анализ, атомно-силовая микроскопия, регуляризация Тихонова-Лаврентьева.

DOI: $10.21883 /$ OS.2022.02.51990.2581-21

\section{Введение}

Тонкопленочные структуры полупроводник-сегнетоэлектрик в настоящее время привлекают большое внимание исследователей благодаря возможности создания на их основе устройств радиофотоники и функциональной микроэлектроники: акустоэлектроники, акустооптики [1-5]. Одним из перспективных полупроводниковых материалов для таких устройств являются тонкие пленки пьезополупроводников, к которым можно отнести тонкие пленки бинарных полупроводников $\mathrm{ZnO}, \mathrm{CdS}$, AlN. Плёнки оксида цинка являются широкозонными и прямозонными полупроводниками. Благодаря прежде всего малым оптическим потерям в УФ и видимом диапазонах спектра, а также величине запрещенной зоны, которая при комнатной температуре составляет около $3.3 \mathrm{eV}$, пленки находят широкое применение в качестве активного материала для микроприборов фотоники и микроэлектроники [1-5].

В этой связи тонкие пленки из $\mathrm{ZnO}$, сформированные на поверхности сегнетоэлектрической подложки из монокристаллического танталата лития, позволяют создавать оптически и электрически управляемые структуры по топологии полевого транзистора или фоторезистора с полевым управлением [6]. Для создания таких микроприборов необходимо проведение комплексного исследования структурных, оптических и люминесцентных свойств тонких пленок оксида цинка в составе структуры пьезополупроводник-сегнетоэлектрик. Настоящая статья является продолжением цикла проводимых работ по исследованию структуры $\mathrm{ZnO}$-сегнетоэлектрик [7-9].

В работе представлены результаты исследования структурных, оптических и фотолюминесцентных свойств тонких пленок оксида цинка в составе тонкопленочных структур $\mathrm{ZnO}-$ танталат лития $\left(\mathrm{ZnO}-\mathrm{LiTaO}_{3}\right)$ и структуры тонкая пленка $\mathrm{ZnO}-$ кварцевая подложка $\left(\mathrm{ZnO}-\mathrm{SiO}_{2}\right)$.

\section{Изготовление образцов}

Тонкопленочные структуры создавались методом лазерной абляции мишени из прессованного порошка $\mathrm{ZnO}$ марки ОСЧ $[8,10-12]$. Поверхность подложек из танталата лития (при создании структур $\mathrm{ZnO}-\mathrm{LiTaO}_{3}$ ) полировалась по 14 классу. Структура $\mathrm{ZnO}-\mathrm{SiO}_{2}$ формировалась на поверхности полированных по 14 классу кварцевых пластин из кварца марки КУ-1. Перед операцией нанесения на поверхность подложки слоя из оксида цинка все подложки очищались от органических загрязнений в полярных и неполярных растворителях. Далее подложки промывались в деионизованной воде, удельное сопротивление которой было не менее $1.0 \mathrm{M} \Omega$. Для финишной очистки от следов загрязнений, а также с 
целью повышения адгезии подложки к наносимой пленке из $\mathrm{ZnO}$ все подложки подвергались ионной бомбардировке (ионному ассестированию) в аргоно-кислородной плазме, которая инициировалась на поверхности подложек, внутри реактора из нержавеющей стали.

Процесс формирования тонких пленок $\mathrm{ZnO}$ методом лазерной абляции проводился в импульсном режиме воздействия лазерного луча на мишень [10-12]. Для исключения расплавления мишени из спрессованного порошка $\mathrm{ZnO}$ и сопутствующего разбрызгивания крупных капель расплава на подложку, а также исключения прожига мишени в процессе напыления осушествлялось сканирование лазерного луча по поверхности мишени. Рабочий объем реактора, в котором проводился синтез пленок оксида цинка, откачивался с помощью двухконтурной безмаслянной системы откачки до остаточного давления, не превышающего $0.01 \mathrm{~Pa}$.

Для реализации процесса лазерной абляции нами был использован самодельный импульсный DPSS YAG Ndлазер, работающий на основной длине волны генерации, равной $1064 \mathrm{~nm}$. Частота следования импульсов лазера могла варьировать в течение процесса нанесения пленки от 40 до $20 \mathrm{~Hz}$. Энергия импульса лазерного излучения составляла $640 \mathrm{~mJ}$. Длительность импульса лазерного излучения лежала в диапазоне 10-12 ns. DPSS-лазер работал в режиме генерации гигантских импульсов, для создания которых была модифицирована схема резонатора промышленного лазера, в которую нами был введен внутрирезонаторный акустооптический модулятор собственной конструкции из парателлурита. Коллимированный поток лазерного излучения вводился в объем реакционной камеры через сапфировое окно. Лазерное излучение фокусировалось на поверхность мишени из $\mathrm{ZnO}$ в пятно, диаметр которого не превышал $500 \mu \mathrm{m}$. Распределение мощности лазерного излучения по сечению пучка описывалось гауссианой.

Температура подложки из ниобата лития поддерживалась примерно равной $250^{\circ} \mathrm{C}$, что гарантировало сохранение сегнетоэлектрической фазы подложки из монокристаллического танталата лития. Нагрев сегнетоэлектрической подложки осуществлялся с помощью освещения подложки ИК лампой. Толщина пленки оксида цинка в процессе роста на подложке регистрировалась с помощью кварцевых микровесов. В результате импульсного лазерного напыления на поверхности подложки из $\mathrm{LiTaO}_{3}$ были сформированы слои из оксида цинка толщиной $3.0 \mu \mathrm{m}$. Толщина пленки оксида цинка далее контролировалась с помощью интерференционного микроскопа.

\section{Экспериментальные результаты}

Рентгеноструктурные исследования пленок оксида цинка проводились на дифрактометре ДРОН-3М. Для исследований использовалось излучение $\mathrm{CuK}_{\alpha}$ с длиной волны, равной $1.5418 \AA$. Сравнение дифрактограмм

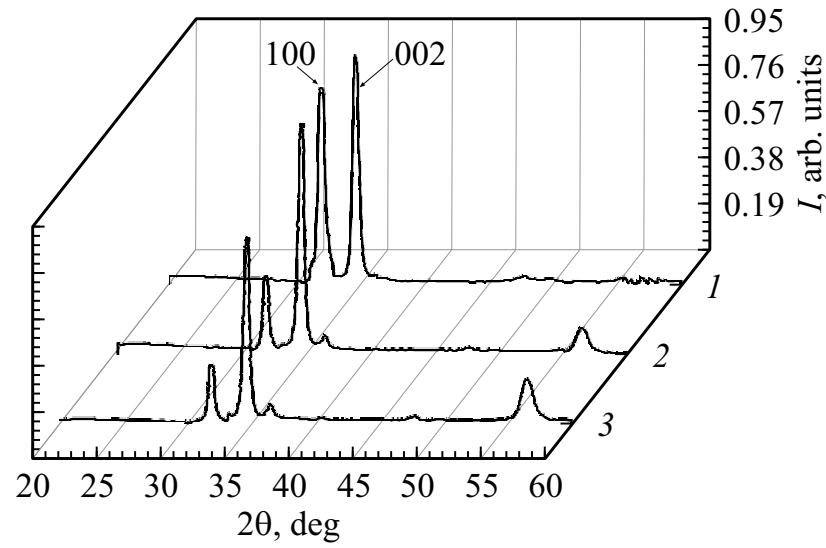

Рис. 1. Рентгенограммы пленки оксида цинка: кривая $1-$ синтезированной на кварцевой подложке, 2 - синтезированной на нагретой подложке из танталата лития, 3 - синтезированной на холодной подложке из танталата лития.

структур оксид цинка-кварц, оксид цинка на поверхности танталата лития при температуре $250^{\circ} \mathrm{C}$ и оксид цинка на поверхности подложки из танталата лития без предварительного нагрева приведены на рис. 1 (кривые 1,2 и 3 соответственно). По данным рентгеноструктурного анализа синтезируемые пленки имеют во всех случаях нанокристаллическую структуру. Размеры кристаллов $\mathrm{ZnO}$ в объеме тонкой пленке оксида цинка (в структуре $\mathrm{ZnO}-\mathrm{LTaO}_{3}$ ), вычисленные по формуле Селякова-Шеррера [13], не превышали $16 \mathrm{~nm}$, а размеры нанокристаллов в слое $\mathrm{ZnO}$, нанесенного на кварцевую подложку, не превышали $12 \mathrm{~nm}$. На дифрактограммах всех синтезированных пленок оксида цинка присутствует дифракционный максимум гексагонального $\mathrm{ZnO}$ (002) большой интенсивности. Поэтому можно утверждать о наличии высокого структурного совершенства в синтезируемых импульсной лазерной абляцией пленках. Кроме того, следует отметить наличие выделенной осевой текстуры в направлении оси $\mathbf{C}$, которая расположена перпендикулярно к поверхности подложки. У пленки оксида цинка, синтезированной на поверхности танталата лития с предварительным нагревом (рис. 1, кривая 2), в сравнении с положением пиков дифрактограммы для пленки, синтезированных на кварцевой подложке (рис. 1, кривая 1), наблюдается уменьшение интенсивности пика (100) с уровня 0.8 до величины 0.33 . Угловое положение пиков (100) и (002) не изменяется, что свидетельствует об отсутствии сжатия или растяжения пленки оксида цинка при ее синтезе на нагретой подложке из танталата лития. На дифрактограммах (рис. 1, кривые 2 и 3) для пленок $\mathrm{ZnO}$, сформированных на горячей или холодной сегнетоэлектрической подложках, присутствуют рефлексы (101), (110), которые отсутствуют на дифрактограмме для пленки оксида цинка, созданной на поверхности кварцевой пластины. Очень слабый рефлекс (102) в окрестности угла $48^{\circ}$ присутствует на дифрактограммах для всех исследуемых 
нами пленок. Интенсивность этого рефлекса неизменна независимо от типа используемой подложки или температуры подложки. Следует отметить, что интенсивность рефлекса (100) у пленки, синтезированной на подложке из $\mathrm{LiTaO}_{3}$ без предварительного нагрева, уменьшилась на $13 \%$ относительно интенсивности аналогичных пиков (рефлексов) на дифрактограммах пленок, синтезированных на предварительно нагретой подложке $\mathrm{LiTaO}_{3}$, и уменьшилась на 57\% относительно интенсивности рефлекса для пленок, сформированных на кварцевой подложке. В свою очередь интенсивность пика (002) на дифрактограммах, соответствующих синтезированной пленке на кварцевой подложке и на предварительно нагретой подложке из $\mathrm{LiTaO}_{3}$, осталась без изменений. Для случая синтеза пленки оксида цинка на холодной подложке из $\mathrm{LiTaO}_{3}$ интенсивность пика (002) стала меньше на $15 \%$ в сравнении с интенсивностью аналогичного рефлекса для случая пленки, синтезированной на горячей подложке из $\mathrm{LiTaO}_{3}$ или из кварца. Рефлекс (101) малой интенсивности в окрестности $36^{\circ}$ на дифрактограмме пленки, синтезированной на кварцевой подложке, на дифрактограммах для пленок $\mathrm{ZnO}$, синтезированных на сегнетоэлектрической подложке из $\mathrm{LiTaO}_{3}$, сдвинут в сторону больших углов на $1.3^{\circ}$ и возрастает по интенсивности в два раза для случая синтеза пленки $\mathrm{ZnO}$ на нагретой подложке и увеличивается в 3.6 раза для случая синтеза на холодной подложке. Рефлекс (110), отсутствующий на дифрактограмме для пленки $\mathrm{ZnO}$, сформированной на кварцевой подложке, появляется в окрестности угла $56^{\circ}$ на дифрактограммах пленок $\mathrm{ZnO}$, созданных на подложках $\mathrm{LiTaO}_{3}$. Интенсивность этого пика растет, когда пленка оксида цинка растет на холодной подложке, и она в 1.8 раза больше аналогичного пика для случая создания пленки оксида цинка на предварительно нагретой подложке танталата лития. Сравнение литературных данных по виду дифрактограмм для пленок оксида цинка, синтезированных методом магнетронного распыления мишени из $\mathrm{ZnO}$ [1416], с результатами рентгеноструктурного анализа, соответствующего пленкам оксида цинка, синтезированным импульсной лазерной абляцией на горячей и холодной подложках из танталата лития, позволяет утверждать о хорошем совпадении значений интенсивности для рефлексов (100) и (002). Кроме того, угловое положение рефлексов (100) и (002) для всех случаев синтезированных нами пленок оксида цинка хорошо коррелирует с литературными данными [8,14-16]. Совместный анализ вида дифрактограмм для синтезированной пленки оксида цинка по технологии импульсной лазерной абляции распыления высокочистой мишени из прессованного порошка $\mathrm{ZnO}$ и дифрактограмм для случая магнетронного распыления мишени из $\mathrm{ZnO}[4,14-16]$ показал отсутствие дифракционных максимумов (100), (101), (102) и (110) на дифрактограммах образцов, созданных методом магнетронного распыления. Проведенные исследования шероховатости поверхности пленок на сканирующем зондовом микроскопе Solver PRO (фирмы
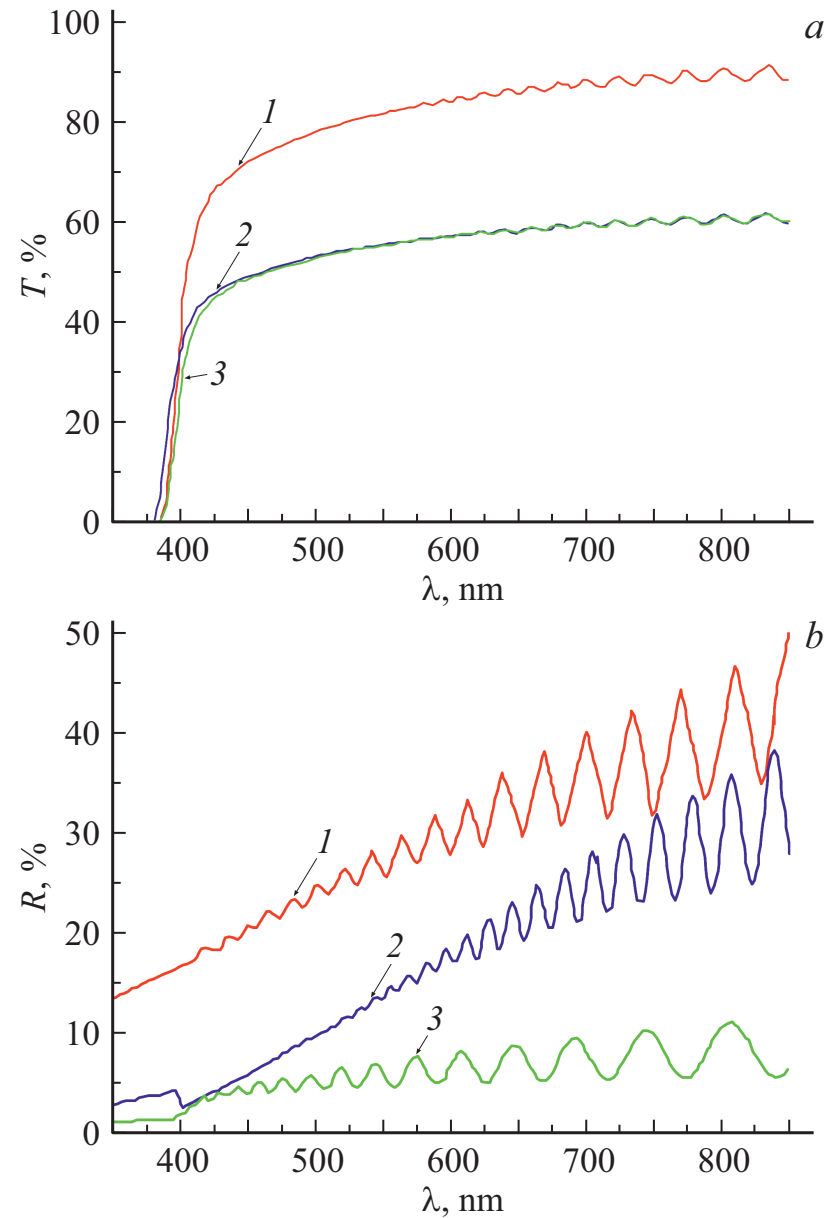

Рис. 2. (a) Спектры пропускания пленки $\mathrm{ZnO}$ : кривая 1 слой $\mathrm{ZnO}$ нанесен на кварцевую подложку, $2-$ слой $\mathrm{ZnO}$ нанесен на монокристаллический $\mathrm{LiTaO}_{3}$, синтез проведен на нагретой подложке, 3 - слой $\mathrm{ZnO}$ нанесен на монокристаллический $\mathrm{LiTaO}_{3}$, синтез проведен на подложке без нагрева. (b) Спектры отражения пленки $\mathrm{ZnO}$ : кривая 1 - пленка $\mathrm{ZnO}$ нанесена на кварцевую подложку, 2 - пленка $\mathrm{ZnO}$ нанесена на монокристаллический $\mathrm{LiTaO}_{3}$, синтез проведен на нагретой подложке, 3 - пленка $\mathrm{ZnO}$ нанесена на монокристаллический $\mathrm{LiTaO}_{3}$, синтез проведен на подложке без нагрева.

НТ-МДТ) показали высокое структурное совершенство пленки, синтезированной методом лазерной абляции как на подложке из кварца, так и на подложке из $\mathrm{LiTaO}_{3}$. Шероховатость пленки $\mathrm{ZnO}$ на кварцевой подложке не превышала $80.0 \mathrm{~nm}$, а шероховатость пленки $\mathrm{ZnO}$, созданной на сегнетоэлектрической подложке из $\mathrm{LiTaO}_{3}$, не превышала $97.0 \mathrm{~nm}$.

Для изучения оптических свойств полученной пленки оксида цинка в УФ и видимом диапазонах спектра были проведены исследования спектров пропускания и отражения. Исследование спектров пропускания и отражения (рис. 2, $a$ и рис. 2,b) проводились в диапазоне длин волн от 300 до $800 \mathrm{~nm}$ на спектрометре Perkin Elmer Lambda 650. Измерения проводились при комнатной температуре. 


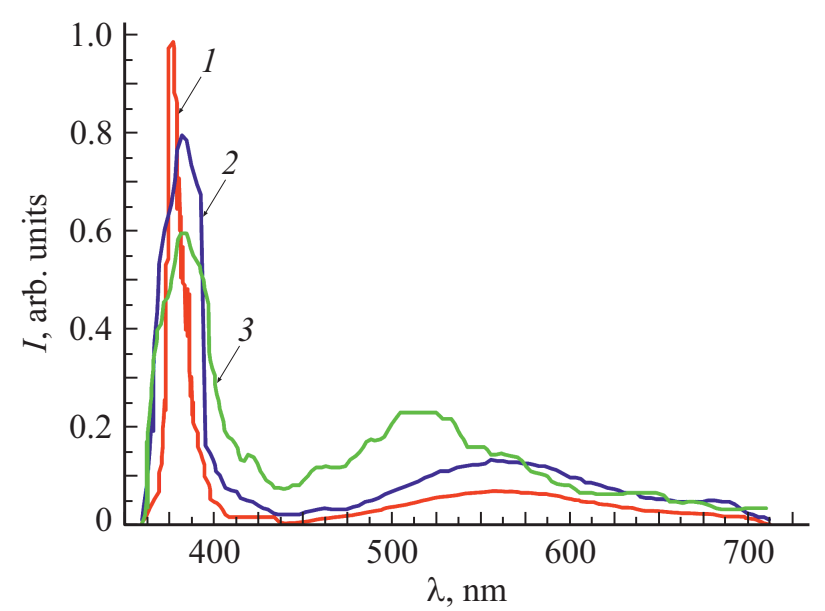

Pис. 3. Спектры фотолюминесценции тонких пленок оксида цинка: кривая $1-\mathrm{ZnO}$ нанесен на кварцевую подложку, $2-$ $\mathrm{ZnO}$ нанесен на монокристаллический $\mathrm{LiTaO}_{3}$, синтез проведен на нагретой подложке, $3-\mathrm{ZnO}$ нанесен на монокристаллический $\mathrm{LiTaO}_{3}$, синтез проведен на подложке без нагрева.

Спектры пропускания оксида цинка приведены на рис. 2, $a$. Из спектра пропускания видно, что в диапазоне длин волн 400-850 nm коэффициент пропускания $(T)$ у пленки $\mathrm{ZnO}$, напыленной на кварц, достигает 85\%, a у пленки $\mathrm{ZnO}$, напыленной на поверхность монокристаллического танталата лития, не превышает 58\%. На спектре пропускания видны осцилляции, обусловленные эффектом интерференции в тонкой пленке.

Спектр отражения пленок $\mathrm{ZnO}$ приведен на рис. $2, b$. На спектре отражения также наблюдаются осцилляции, обусловленные эффектом интерференции света в тонких пленках. С помощью совместного анализа спектров пропускания и отражения, а также с учетом анализа интерференционных полос в спектрах пропускания и отражения по методике [7-9,14] был определен показатель преломления для пленок оксида цинка, который составил 2.36. Полученное значение показателя преломления соответствует значениям, полученным для пленок оксида цинка, синтезированных реактивным магнетронным распылением $[8,14,15]$. Совместный анализ результатов рентгеновских дифрактограмм, данных AFM и спектральных зависимостей $T(\lambda)$ и $R(\lambda)$ позволяет утверждать, что методом лазерной абляции в режиме гигантских импульсов удалось сформировать тонкие пленки из оксида цинка с малым количеством структурных дефектов на поверхности сегнетоэлектрической подложки из тантала лития.

Спектральная зависимость коэффициента поглощения синтезированной методом лазерной абляции пленки $\mathrm{ZnO}$ была получена с помощью метода, описанного в работах [7-9]. Для определения оптической ширины запрещенной зоны спектр поглощения пленки $\mathrm{ZnO}$ был перестроен в координатах $\left(\alpha^{2}-h v\right)$, и методом линеаризации переходной области были определены значения оптической ширины запрещенной зоны. Для пленки оксида цинка, нанесенной на поверхность кварцевой подложки, оптическая ширина запрещенной зоны составила $3.29 \mathrm{eV}$. Величина оптической запрещенной зоны для пленки оксида цинка, нанесенной на поверхность предварительно нагретой монокристаллической подложки из танталата лития, составила $3.28 \mathrm{eV}$. Величина оптической запрещенной зоны для пленки оксида цинка, нанесенной на поверхность монокристаллической подложки из танталата лития без предварительного нагрева, составила $3.28 \mathrm{eV}$. Сравнивая полученные результаты по определению оптической ширины запрещенной зоны в пленках $\mathrm{ZnO}$ с результатами аналогичного исследования, проведенного нами ранее для тонких пленок $\mathrm{ZnO}$, синтезированных на поверхности ниобата лития или полированной ЦТСЛ-керамики [7-9], можно констатировать, что на поверхности монокристаллического тантала лития методом лазерной абляции в режиме гигантских импульсов удается сформировать тонкие пленки оксида цинка, оптические свойства которых близки к свойствам эпитаксиальных пленок оксида цинка.

Для исследования параметров оптически активных ловушек, присутствующих в пленке оксида цинки, оценки концентрации и частотного фактора этих ловушек были проведены исследования фотолюминесцентных свойств (рис. 3). Изучение фотолюминесценции проводилось на люминесцентном спектрометре Perkin Elmer LS50B при комнатной температуре без продувки рабочей камеры сухим азотом. Длина волны возбуждающего излучения составляла $320 \mathrm{~nm}$. Спектры фотолюминесценции исследуемых структур приведены на рис. 3 (кривые 1-3). На всех спектрах исследуемых структур присутствует узкая интенсивная полоса люминесценции, находящаяся в УФ области, максимум которой находится в окрестности длины волны, равной $380 \mathrm{~nm}$. Максимум полосы люминесценции, соответствующей слою $\mathrm{ZnO}$, нанесенному на поверхность $\mathrm{SiO}_{2}$ (рис. 3, кривая 1), находится на длине волны $377 \mathrm{~nm}$ и имеет полуширину $12 \mathrm{~nm}$, что совпадает с литературными данными для фотолюминесценции пленки $\mathrm{ZnO}$, нанесенной на кварцевую подложку $[7,8]$. Максимум полосы люминесценции, соответствующей слою $\mathrm{ZnO}$, нанесенному на предварительно нагретую поверхность танталата лития (рис. 3, кривая 2), находится на длине волны $382 \mathrm{~nm}$ и имеет полуширину $45 \mathrm{~nm}$. Кроме того, эта полоса имеет меньшую интенсивность (на 18\% ее интенсивность меньше, чем интенсивность аналогичной полосы спектра фотолюминесценции для пленки $\mathrm{ZnO}$, напыленной на кварцевую подложку). Максимум полосы люминесценции, соответствующей слою $\mathrm{ZnO}$, нанесенному на поверхность танталата лития без предварительного нагрева (рис. 3, кривая 3), находится на длине волны $382 \mathrm{~nm}$ и имеет полуширину $48 \mathrm{~nm}$. Эта полоса имеет самую слабую интенсивность среди всех нами рассмотренных (ее интенсивность меньше на 41\%, чем интенсивность аналогичной полосы спектра фотолюминесценции для пленки $\mathrm{ZnO}$, напыленной на кварцевую подложку). Сдвиг полосы УФ фотолюминесценции на $5 \mathrm{~nm}$ в сторону больших 
длин волн может быть связан с тем, что наблюдаемая фотолюминесценция в пленке оксида цинка, нанесенного на сегнетоэлектрическую подложку, является суммарным эффектом люминесценции как от экситонных комплексов, так и от глубоких ловушек, присутствующих в объеме пленки оксида цинка. Если сравнить положение и интенсивность УФ полосы, наблюдаемой в спектре фотолюминесценции пленок оксида цинка, нанесенных на поверхность тантала лития, с положением и интенсивностью УФ полосы фотолюминесценции пленки оксида цинка, нанесенной на поверхность ниобата лития, то максимум пика УФ фотолюминесценции для $\mathrm{ZnO}$ на поверхности из ниобата лития находится на длине волны $388 \mathrm{~nm}$, и интенсивность этого пика УФ фотолюминесценции меньше на $13 \%$. Полуширина УФ пика фотолюминесценции для слоя $\mathrm{ZnO}$, напыленного на подложку из ниобата лития, составляет около $50 \mathrm{~nm}$, что незначительно превышает полуширину аналогичного пика полосы УФ фотолюминесценции для тонкой пленки $\mathrm{ZnO}$, сформированной на подложке из $\mathrm{LiTaO}_{3}$. Для всех исследуемых образцов положение максимумов узких полос фотолюминесценции в УФ области спектра, а также спектральная полуширина этих пиков позволяют предположить, что эти полосы фотолюминесценции преимущественно обусловлены экситонным механизмом люминесценции $[14,16,17]$. Значительно отличающаяся интенсивность полос УФ люминесценции позволяет утверждать, что концентрации экситонов в слое полупроводника в структурах $\mathrm{ZnO}^{-\mathrm{SiO}_{2}}$ и $\mathrm{ZnO}$-танталат лития имеют различные значения. Наблюдаемый спектральный сдвиг максимумов в сторону более длинных волн и значительное увеличение полуширины УФ пика позволяют предположить, что в процесс фотолюминесценции вовлекаются глубокие ловушки, которые имеют энергетическое распределение около $3.0 \mathrm{eV}$. Таким образом, наибольшая концентрация экситонов содержится в объеме полупроводниковой пленки $\mathrm{ZnO}$, синтезированной на подложке из кварца. Несколько меньшая концентрация экситонов присутствует в пленке оксида цинка, сформированной на предварительно нагретой подложке из монокристаллического танталата лития. Наименьшая концентрация экситонов наблюдалась в пленке оксида цинка, созданной на поверхности из монокристаллического танталата лития без предварительного нагрева. В пользу суммарного механизма фотолюминесценции, обусловленного люминесценцией экситонов и глубоких ловушек, свидетельствует то, что энергия активации оптически активных ловушек, ответственных за УФ пик фотолюминесценции, лежит в диапазоне от 3.0 до $3.3 \mathrm{eV}$.

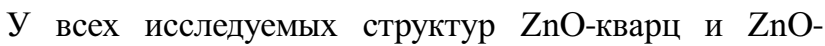
сегнетоэлектрик наблюдаются широкие полосы люминесценции, лежащие в сине-зеленой области спектра. Кроме того, эти широкие полосы фотолюминесценции имеют сильно различающиеся значения полуширины и интенсивности. Интенсивность широкой полосы фотолюминесценции тонкой пленки $\mathrm{ZnO}$ на кварцевой подложке минимальна в сравнении с полосой для образца
Таблица 1

\begin{tabular}{c|c|c}
\hline № & $\begin{array}{c}\text { Энергия } \\
\text { активации, } \mathrm{eV}\end{array}$ & $\begin{array}{c}\text { Величина частотного } \\
\text { фактора, } \mathrm{s}^{-1}\end{array}$ \\
\hline 1 & 3.3 & $6.6 \cdot 10^{-9}$ \\
2 & 3.2 & $8.8 \cdot 10^{-9}$ \\
3 & 3.18 & $5.6 \cdot 10^{-9}$ \\
4 & 2.48 & $2.3 \cdot 10^{-8}$ \\
5 & 2.37 & $7.6 \cdot 10^{-7}$ \\
6 & 2.26 & $4.5 \cdot 10^{-7}$ \\
7 & 1.98 & $3.3 \cdot 10^{-7}$ \\
8 & 1.94 & $6.8 \cdot 10^{-7}$ \\
9 & 1.92 & $3.8 \cdot 10^{-7}$
\end{tabular}

тонкой пленки $\mathrm{ZnO}$, напыленной на монокристаллическую подложку $\mathrm{LiTaO}_{3}$. Ее максимум находится на длине волны $557 \mathrm{~nm}$, а полуширина - наибольшая из всех и составляет $114 \mathrm{~nm}$. Для пленки $\mathrm{ZnO}$, сформированной на нагретой подложке из $\mathrm{LiTaO}_{3}$, интенсивность этой широкой полосы больше в 2.3 раза интенсивности полосы фотолюминесценции, рассмотренной нами ранее. Интенсивность широкой полосы фотолюминесценции пленки $\mathrm{ZnO}$, синтезированной на монокристаллической подложке из $\mathrm{LiTaO}_{3}$ без предварительного нагрева, среди всех рассмотренных имеет наибольшую интенсивность: она в 5 раз интенсивнее в сравнении с аналогичной полосой фотолюминесценции для пленки оксида цинка, нанесенной на кварц. Положение максимума пика сине-зеленой фотолюминесценции практически совпадает для пленок оксида цинка, сформированных на кварцевой подложке и на предварительно нагретой подложке из танталата литии, и находится в окрестности $560 \mathrm{~nm}$. Положение максимума пика фотолюминесценции для пленки оксида цинка, напыленной на холодную подложку из тантала лития, смещено в область более коротких длин волн, максимум лежит в диапазоне длин волн $512-515 \mathrm{~nm}$. Наличие этих полос в спектре фотолюминесценции может быть обусловлено люминесценцией оптически активных дефектов с энергией активации от 2.48 до $1.97 \mathrm{eV}$. К таким дефектам, ответственным за фотолюминесценцию в этом спектральном диапазоне, можно отнести вакансии кислорода, которые являются оптически активными дефектами. Эти дефекты образуются при синтезе пленки $\mathrm{ZnO}$ методом лазерной абляции изза нарушения стехиометрического состава оксида цинка вследствие недостатка кислорода в процессе напыления и дальнейшего отсутствия отжига в кислородной среде.

Спектры фотолюминесценции для тонкой пленки $\mathrm{ZnO}$, нанесенной на подложки из кварца и из танталата лития, были обработаны с помощью метода регуляризации Тихонова-Лаврентьева. Это позволило получить энергетический спектр и наиболее вероятные значения частотного фактора для оптически активных ловушек, ответственных за процессы фотолюминесценции, которые присутствуют в слое оксида цинка (табл. 1-3). 
Таблица 2

\begin{tabular}{c|c|c}
\hline № & $\begin{array}{c}\text { Энергия } \\
\text { активации, } \mathrm{eV}\end{array}$ & $\begin{array}{c}\text { Величина частотного } \\
\text { фактора, } \mathrm{s}^{-1}\end{array}$ \\
\hline 1 & 3.3 & $3.6 \cdot 10^{-9}$ \\
2 & 3.18 & $9.8 \cdot 10^{-9}$ \\
3 & 3.11 & $6.4 \cdot 10^{-9}$ \\
4 & 2.61 & $2.9 \cdot 10^{-7}$ \\
5 & 2.51 & $1.2 \cdot 10^{-7}$ \\
6 & 2.48 & $7.5 \cdot 10^{-7}$ \\
7 & 2.44 & $3.6 \cdot 10^{-7}$ \\
8 & 2.37 & $8.3 \cdot 10^{-7}$ \\
9 & 2.26 & $2.6 \cdot 10^{-7}$ \\
10 & 1.84 & $6.5 \cdot 10^{-7}$ \\
11 & 1.82 & $3.3 \cdot 10^{-7}$ \\
\end{tabular}

Таблица 3

\begin{tabular}{c|c|c}
\hline № & $\begin{array}{c}\text { Энергия } \\
\text { активации, } \mathrm{eV}\end{array}$ & $\begin{array}{c}\text { Величина частотного } \\
\text { фактора, } \mathrm{s}^{-1}\end{array}$ \\
\hline 1 & 3.30 & $7.6 \cdot 10^{-9}$ \\
2 & 3.10 & $9.8 \cdot 10^{-8}$ \\
3 & 3.00 & $6.4 \cdot 10^{-8}$ \\
4 & 2.98 & $2.9 \cdot 10^{-8}$ \\
5 & 2.61 & $1.2 \cdot 10^{-7}$ \\
6 & 2.57 & $7.5 \cdot 10^{-7}$ \\
7 & 2.51 & $3.6 \cdot 10^{-7}$ \\
8 & 2.43 & $8.3 \cdot 10^{-7}$ \\
9 & 2.35 & $2.6 \cdot 10^{-7}$ \\
10 & 2.26 & $6.5 \cdot 10^{-7}$ \\
11 & 1.98 & $3.3 \cdot 10^{-7}$ \\
12 & 1.84 & $6.5 \cdot 10^{-7}$ \\
13 & 1.82 & $3.3 \cdot 10^{-7}$
\end{tabular}

В табл. 1 представлены результаты численного восстановления методом регуляризации энергетического спектра ловушек и установления наиболее вероятного значения частотного фактора для глубоких ловушек, присутствующих в пленке оксида цинка, нанесенного на кварцевую подложку.

В табл. 2 представлены результаты численного восстановления методом регуляризации энергетического спектра ловушек и установления наиболее вероятного значения частотного фактора для глубоких ловушек, присутствующих в пленке оксида цинка, нанесенного на предварительно нагретую подложку из танталата лития.

Спектр фотолюминесценции для тонкой пленки $\mathrm{ZnO}$, нанесенной на подложку танталата лития без предварительного нагрева, также был обработан с помощью метода регуляризации Тихонова-Лаврентьева. Это позволило получить энергетический спектр оптически активных ловушек и установить наиболее вероятное значение частотного фактора для глубоких ловушек, присутствующих в слое оксида цинка (табл. 3).

Энергия активации оптически активных дефектов и спектральное положение широких максимумов имеет корреляцию с литературными данными [14-17]. Различие интенсивностей широких полос фотолюминесценции может быть обусловлено различной концентрацией вакансий кислорода в объеме пленки $\mathrm{ZnO}$, образующихся при лазерной абляции. Наибольшая концентрация вакансий кислорода наблюдается в слое $\mathrm{ZnO}$, напыленном на подложку из танталата лития без ее предварительного нагрева.

Глубокие ловушки, соответствующие вакансиям кислорода, присутствуют в объеме пленки оксида цинка при ее синтезе на любой подложке [12,14-17]. Вакансии кислорода могут находиться в трех зарядовых состояниях: нейтральном, однократно ионизированном, двукратно ионизированном. Однократно ионизированные вакансии кислорода имеют энергии активации $0.93,0.94,1.82$, $1.84 \mathrm{eV}$, двукратно ионизированные вакансии кислорода имеют следующие энергии активации: $1.03,2.26,2.51$, $2.9 \mathrm{eV}[14,15,17]$.

Участие ловушек с энергией активации, равной 1.82 и $1.84 \mathrm{eV}$, которые можно соотнести с однократно ионизированными вакансиями кислорода, обнаружено во всех спектрах фотолюминесценции исследуемых пленок оксида цинка. Вклад в фотолюминесценцию ловушек с энергией активации, равной $2.26 \mathrm{eV}$, которые могут быть связаны с двукратно ионизированными вакансиями кислорода, также обнаружен во всех спектрах фотолюминесценции исследуемых пленок оксида цинка. В свою очередь вклад ловушек с энергией активации, равной $2.51 \mathrm{eV}$, которые можно связать с двукратно ионизированными вакансиями кислорода, обнаружены только в пленке оксида цинка, синтезированной на поверхности танталата лития. Кроме того, в процессах фотостимулированной генерации неравновесных носителей заряда принимают участие мелкие доноры $[14,17]$.

Таким образом, опираясь на результаты совместного исследования структурных, оптических и фотолюминесцентных свойств пленок из оксида цинка, синтезированной методом лазерной абляции на кварцевой подложке или на предварительно нагретой подложке из танталата лития, можно утверждать, что тонкие пленки обладают малым количеством структурных дефектов и их оптические свойства близки свойствам эпитаксиальным пленок $\mathrm{ZnO}$, полученных методом газотранспортных реакций на кварцевой подложке, или свойствам пленок оксида цинка, синтезированных на поверхности монокристаллического ниобата лития $[8,12,14-17]$.

\section{Заключение}

Метод импульсной лазерной абляции мишени из порошка ZnO марки OCЧ DPSS-лазером (в режиме генерации гигантских импульсов) позволяет создавать на поверхности танталата лития тонкие пленки $\mathrm{ZnO}$ с высоким структурным совершенством. Об этом свидетельствует наличие интенсивных рефлексов (001) и (002) на дифрактограммах исследуемых пленок. 
Оптические свойства тонких пленок $\mathrm{ZnO}$, сформированных на кварцевой подложке или на предварительно нагретой подложке из тантала лития, близки свойствам эпитаксиальных пленок $\mathrm{ZnO}$, полученных методом газотранспортных реакций, или свойствам пленок оксида цинка, синтезированных на поверхности монокристаллического ниобата лития.

В исследуемых пленках оксида цинка обнаружено присутствие однократно и двукратно ионизированных вакансий кислорода. В пленках $\mathrm{ZnO}$, синтезированных на кварцевой подложке и на подложке из предварительно нагретого монокристаллического тантала лития, количество дефектов, обусловленных вакансиями кислорода, имеет соизмеримое значение, и концентрация глубоких ловушек (кислородных вакансий) наименьшая в сравнении с пленкой оксида цинка, нанесенной на подложку из танталата лития без подогрева. В образцах оксида цинка, сформированного на поверхности танталата лития (с предварительным нагревом и без нагрева), обнаружены глубокие ловушки, которые скорее всего локализованы на межфазном интерфейсе полупроводник-сегнетоэлектрик.

Тонкие пленки $\mathrm{ZnO}$, синтезированные на поверхности монокристаллического танталата лития, по совокупности своих структурных, оптических и фотолюминесцентных свойств могут быть использованы для создания планарных люминесцентных приборов и микроприборов радиофотоники. Кроме того, структуры полупроводниксегнетоэлектрик могут быть пригодны для создания приборов функциональной фотоники и функциональной микроэлектроники: акустоэлектронных и акустооптических приборов.

\section{Финансирование работы}

Работа поддержана Министерством науки и высшего образования Российской Федерации (проект „Госзадание“", грант № 075-01024-21-02 от 29.09.2021).

\section{Конфликт интересов}

Авторы заявляют, что у них нет конфликта интересов.

\section{Список литературы}

[1] W.Z. Xu, Z.Z. Ye, Y.J. Zeng, L.L. Chen, F. Zhuge, G.D. Yuan, H.P. He, L.P. Zhu, J.Y. Huang, B.H. Zhao. Appl. Phys. Lett., 91, 173506 (2007). DOI: 10.1063/1.2783262

[2] C.L. Wei, Y.E. Chen, C.C. Cheng, K.S. Kao, D.L. Cheng, P.S. Cheng. Thin Solid Films, 518 (11), 3059 (2010). DOI: 10.1016/j.tsf.2009.07.207

[3] Y.K. Chembo, D. Brunner, M. Jacquot, L. Larger. Rev. Modern Physics, 91 (3), 035006 (2019) DOI: 10.1103/RewModPhys.91.035006

[4] В.А. Кривченко, Д.В. Лопаев, В.В. Пащенко, В.Г. Пирогов, А.Т. Рахимов, Н.В. Суетин, А.С. Трифонов. ЖТФ, 78 (8), 107 (2008).

[5] Т.В. Бланк, А.А. Гольденберг. ФТП, 37 (9), 1035 (2003).
[6] W. Zheng, Li. Chen, W. Di, L. Aidong, N. Ming. Nature Materials, 12, 617 (2013).

[7] Л.В. Григорьев, Я.Б. Егорова, А.А. Быков, А.А. Семенов, А.А. Никитин. Опт. и спектр., 127 (12), 986 (2019). DOI: $10.21883 /$ OS.2022.02.51990.2581-21

[8] Л.В. Григорьев, И.А. Морозов, Н.С. Журавлев, А.А. Семенов, А.А. Никитин. ФТП, 54 (3), 232 (2020). DOI: $10.21883 /$ OS.2022.02.51990.2581-21

[9] L.V. Grigoryev, A.F. Kraycko, A.V. Mikhailov, V.G. Nefedov, O.V. Shakin. Springer Proceeding of Physics, Advanced Materials, Proceedings of the International Conference on: Physics and Mechanics of New Materials and their Applications", PHENMA-17 (Springer, Jabalpur, 2017), V. 207, ch. 19, p. 239. DOI: 10.1007/978-3-319-78919-4

[10] О.Г. Вендик, В.Ф. Горин. Корпускулярно-фотонная технология (Высшая школа, М., 1984).

[11] S. Hermann, T. Dezhindar, H. Harder, R. Brendel, M. Seibt, S. Stroj. J. Appl. Phys., 108, 114514 (2010). DOI: $10.1063 / 1.3493204$

[12] W. Prellier, A. Fouchet, B. Mercey, Ch. Simon, D. Raveau. Appl. Phys. Lett., 82, 3490 (2003). DOI: $10.1063 / 1.1578183$

[13] А.А. Русаков. Рентгенография металлов (Атомиздат, М., 1977).

[14] P. Narin, E. Kutlu, G.'Atmaca, A. Atilgan, A. Yildiz, S. Lisesivdin. Optics, 168, 86 (2018). DOI: $10.1016 /$ j.ijleo.2018.04.089

[15] U. Helmensonn, M. Latemann, J. Bohlmark, A. Ehiasarian. J. Gudmundsson. Thin Solid Films, 513(1), 1 (2006). DOI: $10.1016 /$ j.tsf.2006.03.033

[16] B.D. Yao, V.F. Chang, N. Wang. Appl. Phys. Lett., 81, 757 (2002). DOI: $10.1063 / 1.1495878$

[17] D.M. Bagnal, Z. Chen, N. Yao. Appl. Phys. Lett., 73, 1038 (1998). DOI: 10.1063/1.122077 